\title{
5-Vinylquinoline-substituted nitrofurans as inhibitors of trypanothione reductase and antitrypanosomal agents
}

\author{
Diego Benitez ${ }^{1}$,
}

Marcelo A. Comini',

Žilvinas Anusevičius ${ }^{2}$,

Jonas Šarlauskas ${ }^{2}$,

Valè Miliukiené

Eglè Miliuvien $\dot{e}^{3}$,

\author{
Narimantas Čènas ${ }^{2 *}$ \\ ${ }^{1}$ Laboratory Redox Biology \\ of Trypanosomes, \\ Institut Pasteur de Montevideo, \\ Mataojo 2020, \\ Montevideo 11400, Uruguay \\ ${ }^{2}$ Institute of Biochemistry \\ of Vilnius University, \\ 7 Saulètekio Avenue, \\ 10257 Vilnius, Lithuania \\ ${ }^{3}$ Vilnius University Hospital \\ Santaros Klinikos, \\ 2 Santariškiu Street, \\ 08406 Villnius, Lithuania
}

Trypanothione reductase (TR) and trypanothione synthase (TS) are critical for the maintenance of thiol-redox homeostasis and antioxidant protection in trypanosomal parasites, which cause African sleeping sickness and Chagas disease. Both enzymes are absent in mammals. Thus, the design of efficient and specific TR and TS inhibitors represents one of the pathways for a development of new antitrypanosomal drugs. 5-Vinylquinoline-substituted nitrofurans $(n=7)$, studied in this work, acted as un- or noncompetitive to trypanothione inhibitors of Trypanosoma congolense TR. Their inhibition constants $\left(K_{\mathrm{i}}\right)$ varied from $2.3 \mu \mathrm{M}$ to $150 \mu \mathrm{M}$. We for the first time observed a parallelism between their antitrypanosomal in vitro activity and their efficacy as TR inhibitors. The inhibition of TS appears not to be a significant factor of trypanocidal activity of examined compounds.

Key words: nitrofurans, trypanothione reductase, inhibition, trypanosomes

Abbreviations: $\mathrm{ArNO}_{2}$, nitroaromatic compound; $\mathrm{EC}_{50}$, compound concentration causing $50 \%$ parasite growth inhibition; $\mathrm{CL}_{50}$, compound concentration for $50 \%$ cell survival; FBS, fetal bovine serum; HGR, human erythrocyte glutathione reductase; $k_{\text {cat }}$ catalytic constant; $K_{\mathrm{i}}$, inhibition constant; PfGR, Plasmodium falciparum glutathione reductase; TR, trypanothione reductase; TS, trypanothione synthase; $\mathrm{T}(\mathrm{SH})_{2}$, dihydrotrypanothione; $\mathrm{TS}_{2}$, trypanothione disulfide.

\section{INTRODUCTION}

The protozoan parasites belonging to the genus Trypanosoma cause African sleeping sickness and Chagas disease, and infect more than 10 million people worldwide [1]. More than 50\% infections are cured by the classical drugs nifurtimox and

\footnotetext{
* Corresponding author. Email: narimantas.cenas@bchi.vu.lt
}

benznidazole (Fig. 1), which are used since 1970s [1]. Recently, a new 5-nitroimidazole derivative, fexinidazole (Fig. 1), has been approved for the oral treatment against sleeping sickness [2]. This shows that in spite of possible side effects, nitroheterocyclic compounds possess a therapeutic potential and perspectives in this area.

Nitroheterocyclic compounds exert their antitrypanosomal activity through several mechanisms 


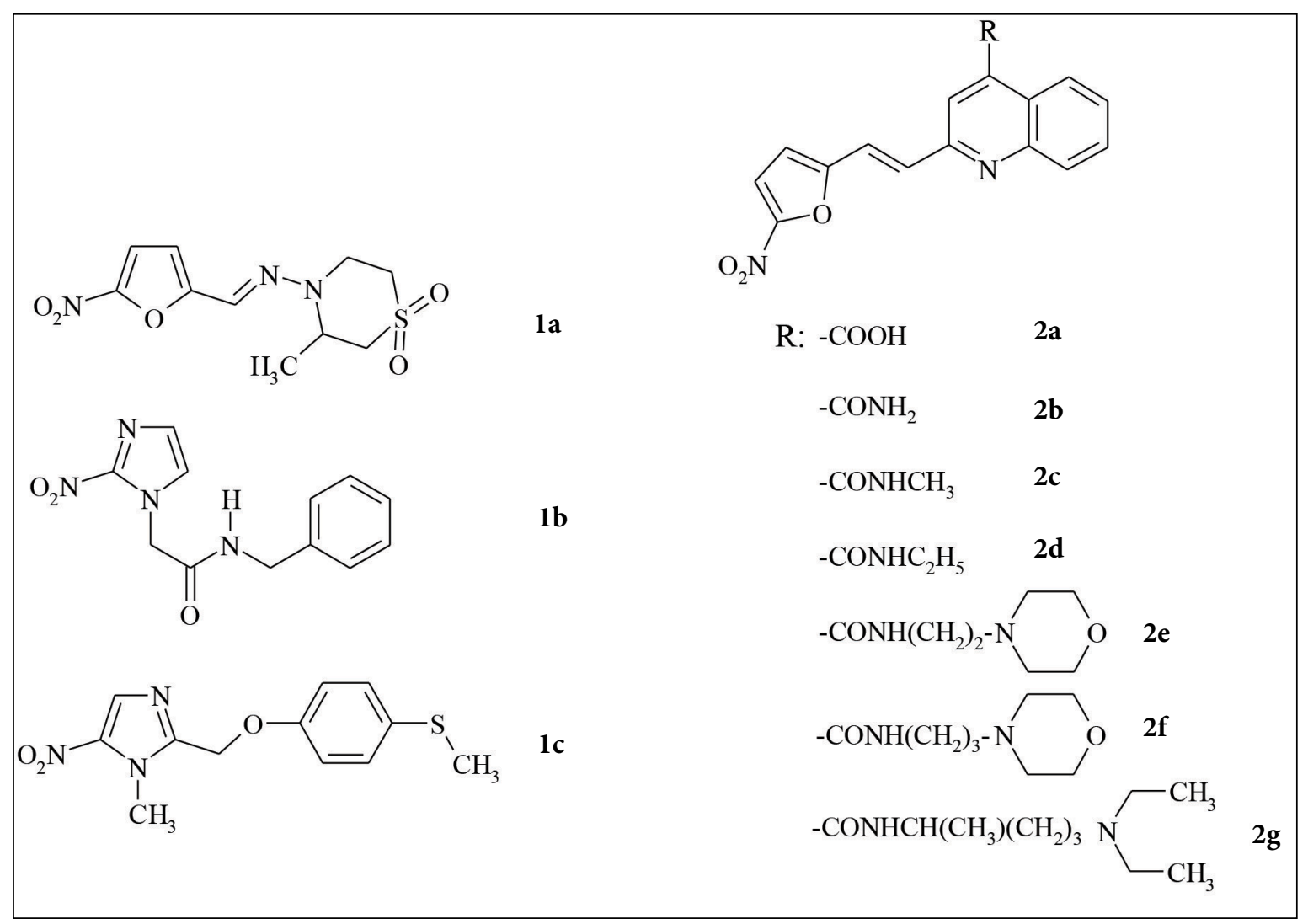

Fig. 1. The formulae of antitrypanosomal drugs nifurtimox (1a), benznidazole (1b) and fexinidazole (1c), and 5-vinylquinolinesubstituted nitrofurans studied in this work $(\mathbf{2} \mathbf{a}-\mathbf{g})$

with an insufficiently understood relative importance. They are enzymatically reduced in a singleelectron way to their nitro anion-radicals, which undergo redox cycling with oxygen and initiate the oxidative stress 3-5]. Another potentially more important factor is their $2 / 4$-electron reduction by NADH-dependent oxygen-insensitive nitroreductase(s), which yields hydroxylamines and their secondary products that alkylate DNA [1, 6, A]. In addition, nitroheterocycles, in particular nitrofurans, inhibit enzyme trypanothione reductase (TR) [4, 8, 9], which is essential for parasite virulency and survival [10]. TR regenerates reduced glutathione-spermidine conjugate, trypanothione $\left(\mathrm{T}(\mathrm{SH})_{2}\right)$, at the expense of NADPH. $\mathrm{T}(\mathrm{SH})_{2}$ is the major low molecular weight antioxidant that is synthesized by trypanothione synthase [11]. Because of the absence of catalase and glutathione-dependent enzymes, the antioxidant system in trypanosomes relies mainly on $\mathrm{TS}_{2}$-dependent enzymes [12, 13]. Thus, the inhibition of TR may weaken the parasite antioxidant system and disturb its redox metabolism and signal transduction [13]. TR is a dimer containing FAD and catalytic disulfide in the $52 \mathrm{kD}$ subunit. The structure of TR is similar to that of human erythrocyte glutathione reductase (HGR) except the negative charge in the $\mathrm{TS}_{2}$-binding site [13, 14]. It is assumed that nitrofurans, like other aromatic TR inhibitors, may bind close to this site ([13, 14], and references therein). In addition, nitrofurans may be slowly reduced by TR in a single-electron way with subsequent redox cycling [4, 8].

Our recent study shows that the antiplasmodial in vitro activity of nitroaromatic compounds may be partly attributed to their inhibition of Plasmodium falciparum glutathione reductase (PfGR) [15]. In this work, we aimed at establishing whether there exists a parallelism between the antitrypanosomal activity of nitrofurans and their efficacy of TR inhibition. Based on previous data [16], we also examined a possibility of the inhibition of TS by nitrofurans.

\section{EXPERIMENTAL}

NADPH was obtained from Sigma-Aldrich, trypanothione was obtained from Bachem Bioscience 
(Switzerland), and were used as received. The other reagents for enzymatic assays and parasite growth studies were of analytical grade and purchased from Sigma-Aldrich, Gibco, Invitrogen, Enzo Life Sciencies and Roche. Vinylquinolinesubstituted nitrofurans 2a-g (Fig. 1) were prepared and characterized as previously described [15, 17]. The octanol/water distribution coefficients of compounds at $\mathrm{pH} 7.0(\log D)$ were calculated using the LogD Predictor (https://chemaxon.com).

The overexpressed trypanothione reductase (TR) from Trypanosoma congolense was prepared as previously described [18]. The enzyme concentration was determined spectrophotometrically using $\varepsilon_{464}=11 \mathrm{mM}^{-1} \mathrm{~cm}^{-1}$. TR and trypanothione were a generous gift of Professor John S. Blanchard (Department of Biochemistry, Albert Einstein College of Medicine, Bronx, NY, USA). The recombinant forms of trypanothione synthetase (TS) from Trypanosoma cruzi, Trypanosoma brucei and Leishmania infantum were prepared as previously described [16].

Kinetic studies of TR were performed in $0.05 \mathrm{M}$ Hepes. pH 7.5, containing $1 \mathrm{mM}$ EDTA at $25^{\circ} \mathrm{C}$ using a Perkin Elmer Lambda 25 UV-VIS spectrophotometer. The rates of NADPH oxidation were determined according to $\Delta \varepsilon_{340}=6.2 \mathrm{mM}^{-1} \mathrm{~cm}^{-1}$. The concentration of $\mathrm{TS}_{2}$ varied from 20 to $150 \mu \mathrm{M}$, the concentration of NADPH was kept saturating, $50 \mu \mathrm{M}$. The enzyme catalytic constant $\left(k_{\text {cat }}\right)$, expressed as a number of moles of NADPH oxidized per mole of active center per second, was obtained by the fitting of kinetic data to the parabolic expression using the SigmaPlot 2000 version 11.0. At infinite $\mathrm{TS}_{2}$ concentration, $k_{\text {cat }}$ was equal to $120 \pm 7.0 \mathrm{~s}^{-1}$. Compound inhibition constants $\left(K_{\mathrm{i}}\right)$ were calculated according to Dixon plots, $1 / k_{\text {cat }}$ vs $[\mathrm{I}]$, where $[\mathrm{E}]$ and $[\mathrm{I}]$ are enzyme and inhibitor concentrations, respectively. In the case of nonlinear Dixon plots (incomplete inhibition), the maximal inhibition degree was obtained by fitting of the inhibition degree vs [I] dependence to the parabolic expression [19].

The inhibitory activity of the compounds towards TS was determined according to the changes in $650 \mathrm{~nm}$ absorbance in the presence and absence of an inhibitor using the 96-well end-point assay as previously described [16]. The reaction mixtures contained $0.15 \mathrm{mM}$ ATP, $2.0 \mathrm{mM}$ spermidine, reduced glutathione at concentrations of 0.05 ,
0.57 and $0.25 \mathrm{mM}$ for TS from T. brucei, T. cruzi and $L$. infantum, respectively, and the examined compound at $30 \mu \mathrm{M}$ concentration in a total volume of $45 \mu$ l. The reaction was started by adding $5 \mu \mathrm{l}$ TS solution, and stopped after 15 min with $200 \mu \mathrm{L}$ BIOMOL Green ${ }^{\mathrm{TM}}$ reagent. The plates were incubated $20 \mathrm{~min}$ at room temperature and then $\mathrm{A}_{650}$ was measured with a MultiScan EX plate reader (Thermo Fisher Scientific). All determinations were performed at least in triplicate.

The antitrypanosomal activity of the compounds was evaluated against the bloodstream form of T. b. brucei strain 427, line $449 \mathrm{hGrx-roGFP2,}$ sensitive to nifurtimox with $\mathrm{EC}_{50}=15 \pm 2.5 \mu \mathrm{M}$ (compound concentration causing 50\% parasite growth inhibition) [20]. The parasites were grown in the HMI-9 medium complemented with $10 \%$ $(\mathrm{v} / \mathrm{v})$ fetal bovine serum (FBS) and antibiotics in a humidified incubator with $5 \% \mathrm{CO}_{2}$ and at $37^{\circ} \mathrm{C}$ [16]. The parasites $\left(5 \times 10^{5}\right.$ cells $/ \mathrm{mL}$, exponential growth phase) in a 96-well culture plate were exposed for $24 \mathrm{~h}$ to fixed $(30 \mu \mathrm{M}$, preliminary screening) or different concentrations $\left(\mathrm{EC}_{50}\right.$ assay) of the compounds dissolved in DMSO. For the preliminary screening, a number of viable parasites in duplicated samples was assessed by counting cells in a Neubauer chamber and using an optical microscope. For the $\mathrm{EC}_{50}$ assay, flow cytometry was used as readout technique [16]. The data were obtained in triplicate, and processed and analysed with the C6Accuri software.

The murine macrophages (line J774) were cultivated in the DMEM medium supplemented with $10 \%$ FBS and antibiotics under humidified 5\% $\mathrm{CO} 2 / 95 \%$ air atmosphere at $37^{\circ} \mathrm{C}$. In cytotoxicity experiments, the cell pellet $\left(5.0 \times 10^{4} \mathrm{cells} / \mathrm{ml}\right)$ in a fresh culture medium was incubated for $24 \mathrm{~h}$ in a 96-well flat bottom microculture plate. Subsequently, the conditioned medium was replaced in each well by the fresh medium alone or with the added compounds, and further incubated for $24 \mathrm{~h}$. The cytotoxicity experiments were repeated in triplicate, the final concentration of DMSO was $1 \% \mathrm{vol} / \mathrm{vol}$. Cell viability was assessed using the WST-1 reagent [21]. Primary murine splenocytes were prepared as previously described [22], resuspended at a concentration of $1.0 \times 10^{6} \mathrm{cells} / \mathrm{ml}$ in the RPMI 1640 medium with 5\% FCS and antibiotics, and incubated for $24 \mathrm{~h}$ at $37^{\circ} \mathrm{C}$ in the humidified atmosphere containing $5 \% \mathrm{CO}_{2}$ in the absence 
or presence of compounds. The final content of DMSO in the medium, $0.6 \%$, did not affect the cell viability. Cell viability was determined according to the Trypan blue exclusion test. In all examined cases, the $\mathrm{EC}_{50}$ and $\mathrm{cL}_{50}$ (compound concentration for $50 \%$ cell survival) values were obtained from dose/ response curves fitted to the sigmoidal equations with errors calculated using error's propagation.

\section{RESULTS}

Two representatives of 5-vinylquinoline-substituted nitrofurans were previously characterized as weak (2a) and relatively potent $(\mathbf{2 g})$ inhibitors of T. congolense trypanothione reductase [8] (Table 1).
In this work, we extended these studies using other compounds of this group. Compound $\mathbf{2 b}$ (Fig. 2a) and compounds $\mathbf{2 a}, \mathbf{2 c}$ and $\mathbf{2 d}$ were uncompetitive to $\mathrm{TS}_{2}$ substrate inhibitors (increased intercepts and unchanged slopes in Lineweaver-Burk plots), whereas compounds $\mathbf{2 e - f}$ with bulky quinoline ring substituents (Fig. 1) were noncompetitive to $\mathrm{TS}_{2}$ inhibitors (increased intercepts and slopes, data not shown). This is in line with previous observations [8]. The obtained inhibition constants $\left(K_{i}\right)$ are given in Table 1. The action of nitrofurans with the micromolar values of $K_{\mathrm{i}}$ (Table 1 ) is characterized by nonlinear Dixon plots (Fig. $2 \mathrm{~B}$ ). This points to an incomplete character of the inhibition [8], which in our cases corresponds to the $85 \div 92 \%$ maximal

Table 1. Inhibition constants $\left(K_{i}\right)$ of vinylquinoline-substituted nitrofurans against trypanothione reductase (TR), glutathione reductase of Plasmodium falciparum (PfGR) and human erythrocytes (HGR), and their octanol/water distribution coefficients at $\mathrm{pH} 7.0(\log \mathrm{D})$

\begin{tabular}{|c|c|c|c|c|}
\hline \multirow{2}{*}{ Compound } & \multicolumn{3}{|c|}{$K_{i}, \mu \mathrm{M}$} & \multirow{2}{*}{$\log D$} \\
\hline & TR & PfGR [15] & HGR [17] & \\
\hline $2 a$ & 150, uncomp. [8] & $9.0 \pm 1.0$ & 3.0 & 0.27 \\
\hline $2 b$ & $3.2 \pm 0.4$, uncomp. & $25 \pm 3.0$ & 2.5 & 2.64 \\
\hline $2 c$ & $85 \pm 3.0$, uncomp. & n.d. & 60 & 2.72 \\
\hline 2d & $110 \pm 7.1$, uncomp. & $115 \pm 17$ & 25 & 2.87 \\
\hline $2 e$ & $85 \pm 2.5$, noncomp. & $75 \pm 10$ & 42.5 & 2.62 \\
\hline $2 f$ & $2.3 \pm 0.3$, noncomp. & $35 \pm 5.0$ & 25 & 2.45 \\
\hline $2 g$ & 4.5, noncomp. [8] & $100 \pm 12$ & 45 & 2.62 \\
\hline
\end{tabular}

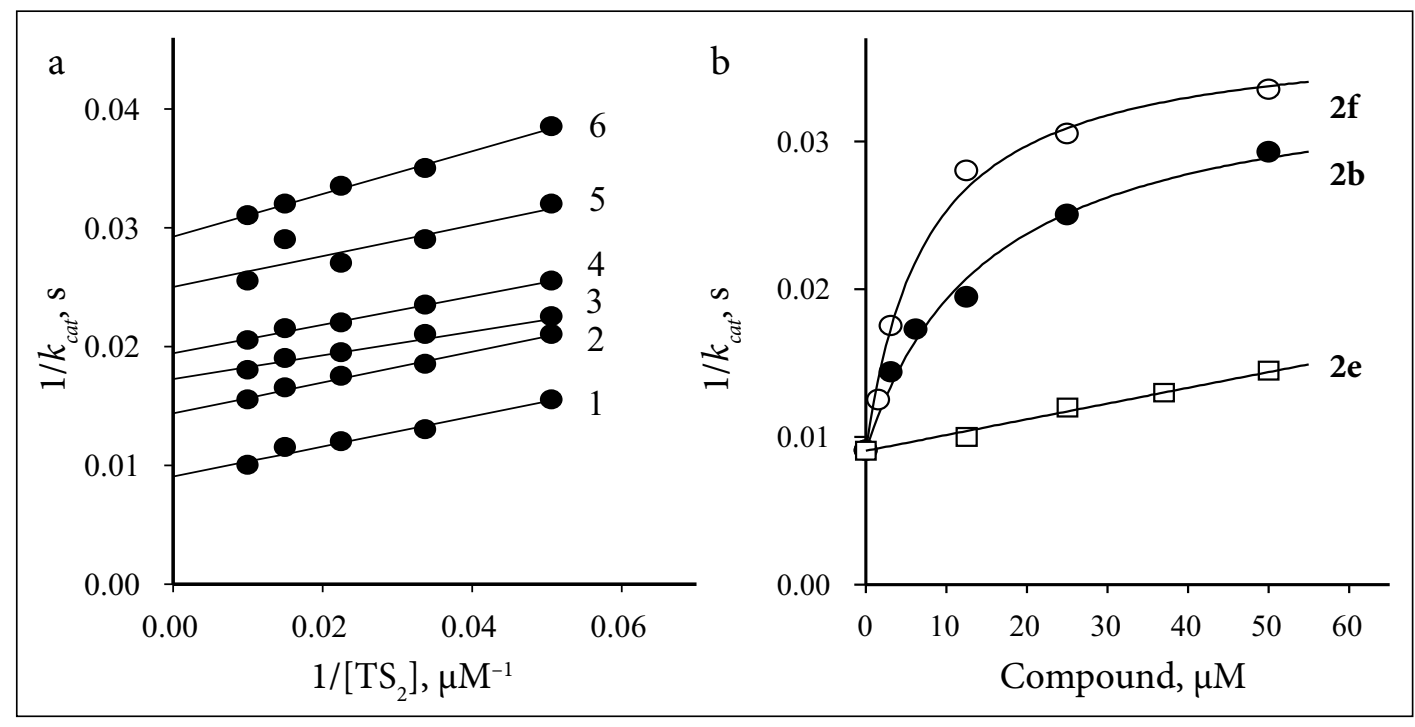

Fig. 2. Inhibition of trypanothione reductase by nitrofurans. (a) Inhibition of TR at the fixed NADPH concentration, $50 \mu \mathrm{M}$, and varied concentrations of TS. Concentration of nitrofuran $2 \mathbf{b}: 0.0 \mu \mathrm{M}(1), 3.1 \mu \mathrm{M}(2), 6.2 \mu \mathrm{M}(3), 12.5 \mu \mathrm{M}(4)$, $25.0 \mu \mathrm{M}(5)$ and $50.0 \mu \mathrm{M}$ (6). (b) Dependence of the reaction $k_{\text {cat }}$ on the inhibitor concentration in Dixon coordinates 
inhibition degree. 5-Vinylquinoline-substituted nitrofurans also act as non- or uncompetitive to glutathione inhibitors of $P$. falciparum (PfGR) and human erythrocyte glutathione reductase (HGR) [14, 16. Their $K_{i}$ values (Table 1) show that the inhibitor specificity of TR and PfGR or HGR is totally different (Table 1). The examined nitrofurans possess a similar lipophilicity $(\log D)$ (Table 1 ), except for that of compound 2a due to the presence of a carboxylate group.

The electron-deficient heteroaromatic compounds such as benzodioxanes may efficiently inhibit another important enzyme of trypanothione metabolism, trypanothione synthetase (TS) [16], which is considered as a potential target of trypanocidal agents. However, the examined nitrofurans were weak inhibitors of this enzyme (Table 2).

Finally, we examined the antitrypanosmal activity of compounds $\mathbf{2 a - 2}$ and their mammalian cell cytotoxicity (Table 3 ). The $\mathrm{EC}_{50}$ values were obtained only for those compounds, which inhib- ited the growth of trypanosomes by $\sim 100 \%$ at their $30 \mu \mathrm{M}$ concentration. The comparison of $\mathrm{EC}_{50}$ of compounds and the data at their fixed concentration enables one to characterize the order of their potency, $\mathbf{2 g}>\mathbf{2 b} \geq \mathbf{2 f}>\mathbf{2 c} \geq \mathbf{2 e} \geq \mathbf{2 d}>\mathbf{2 a}$. One may also note that the examined compounds inhibit the proliferation of mice macrophages at micromolar concentrations, and are cytotoxic with $\mathrm{cL}_{50}=8.9 \div 23.8 \mu \mathrm{M}$ in primary murine splenocytes (Table 3). This may limit the future application of the investigated nitrofurans.

\section{DISCUSSION}

In this work, we studied the inhibition of two enzymes of trypanothione metabolism, TR and TS, by 5 -vinylquinoline-substituted nitrofurans, and its possible relationship with their antitrypanosomal activity. The examined compounds were weak inhibitors of trypanothione synthetase (Table 2). Besides, their similar inhibition efficacy contrasted

Table 2. Inhibition of trypanothione synthetase (TS) by 5-vinylquinoline-substituted nitrofurans

\begin{tabular}{c|c|c|c}
\hline \multirow{2}{*}{ Compound } & \multicolumn{3}{|c}{ \% TS activity at $30 \mu \mathrm{M}$ compound } \\
\cline { 2 - 4 } & Trypanosoma cruzi TS & Leishmania infantum TS & Trypanosoma brucei TS \\
\hline 2a & $95.5 \pm 4.5$ & $95.3 \pm 9.0$ & $83.9 \pm 5.2$ \\
\hline $\mathbf{2 b}$ & $87.7 \pm 1.7$ & $85.5 \pm 5.4$ & $96.9 \pm 6.4$ \\
\hline $\mathbf{2} \mathbf{2 d}$ & $75.2 \pm 5.4$ & $93.6 \pm 9.2$ & $86.6 \pm 5.3$ \\
\hline $\mathbf{2 e}$ & $75.2 \pm 3.8$ & $89.8 \pm 2.7$ & $91.5 \pm 6.1$ \\
\hline $\mathbf{2 f}$ & $63.3 \pm 5.2$ & $101.9 \pm 4.2$ & $99.4 \pm 6.0$ \\
\hline $\mathbf{2 g}$ & $80.6 \pm 2.8$ & $91.3 \pm 11.3$ & $100.2 \pm 4.7$ \\
\hline
\end{tabular}

Table 3. Trypanocidal activity and mammalian cell cytotoxicity of compounds

\begin{tabular}{|c|c|c|c|c|}
\hline \multirow[b]{2}{*}{ Compound } & \multicolumn{2}{|l|}{ T. b. brucei 427} & \multicolumn{2}{|c|}{ Mammalian cell cytotoxicity } \\
\hline & $\begin{array}{c}\text { Growth inhibition at } 30 \mu \mathrm{M}, \\
\%\end{array}$ & $E C_{50}, \mu M$ & $\begin{array}{l}\text { Murine macrophages J774, } \\
E_{5 C_{50}} \mu \mathrm{M}\end{array}$ & $\begin{array}{c}\text { Murine splenocytes } \mathrm{CL}_{50} \text {, } \\
\mu \mathrm{M}\end{array}$ \\
\hline $2 a$ & 23 & n.d & n.d. & $18.7 \pm 2.5$ \\
\hline $2 \mathbf{b}$ & 100 & $3.5 \pm 0.5$ & $<3$ & $23.8 \pm 3.5$ \\
\hline $2 c$ & 77 & n.d. & n.d & $20.0 \pm 3.5$ \\
\hline $2 d$ & 50 & $\sim 30$ & n.d. & $17.5 \pm 3.2$ \\
\hline $2 e$ & 61 & n.d. & n.d & $8.9 \pm 1.9$ \\
\hline $2 f$ & 100 & $4.2 \pm 1.2$ & $<6$ & $19.2 \pm 1.8$ \\
\hline $2 g$ & 100 & $1.7 \pm 0.1$ & $<6$ & $11.1 \pm 2.5$ \\
\hline
\end{tabular}


with the different antitrypanosomal activity (Table 3). For this reason, we further address the properties of trypanothione reductase. According to the crystallographic data of TR complexes with numerous aromatic and heteroaromatic compounds, they bind closely to the $\mathrm{TS}_{2}$-binding site, and most frequently act as noncompetitive to $\mathrm{TS}_{2}$ inhibitors ([13], and references therein). The amino acid residues involved in their binding, Ser-14, Leu-17, Glu-18, Trp-21, Asn-22, Ser-109, Tyr-110, Met-113 and Phe-114, are conserved in TR of T. congolense, T. cruzi and T. brucei [23]. The character of inhibition exerted by compounds $\mathbf{2 a - g}$ (Fig. 2a, Table 1) is consistent with their binding at this domain. In particular, the weak binding of nitrofuran $2 \mathbf{a}$ (Table 1) may be explained by the electrostatic repulsion between its carboxylate group and negatively charged Glu-18,466' [12]. However, the reasons for the different binding affinity of structurally similar $\mathbf{2 b}, \mathbf{2 c}$ and $\mathbf{2 d}$, or $\mathbf{2 e}, \mathbf{2 f}$ and $\mathbf{2 g}$ (Table 1 ) remain unclear, and are beyond the scope of this study.

It is important to note that the compounds $\mathbf{2 b}$, $2 \mathrm{f}$ and $2 \mathrm{~g}$ that inhibit TR with $K_{\mathrm{i}}=2.3 \div 4.5 \mu \mathrm{M}$ (Table 1) possess micromolar values of $\mathrm{EC}_{50}$ against trypanosomes (Table 3), whereas the compounds 2c, $2 \mathrm{~d}$ and $2 \mathrm{e}$ with $K_{\mathrm{i}}=85 \div 110 \mu \mathrm{M}$ are less active $\left(\mathrm{EC}_{50} \leq 30 \mu \mathrm{M}\right)$. The lowest activity of compound 2a $\left(\mathrm{EC}_{50} \gg 30 \mu \mathrm{M}\right)$ is in line with its highest $K_{\mathrm{i}}$, $150 \mu \mathrm{M}$; however, it also may be attributed to its low $\log D$ (Table 1). To the best of our knowledge, this is the first demonstration of the semiquantitative relationship between the antitrypanosomal in vitro activity of a series of homologous compounds, and their efficacy as TR inhibitors. Interestingly, this type of parallelism has not been observed in the recent studies of hybrids of indole and 1,3-thiazole [24, 25], and amides of 5-nitrofuran-2-carbonic acid [9]. In our opinion, this may be attributed to the presence of a great variety of functional groups in the investigated compounds, and/or to the differences in their lipophilicity.

In this context, one should also mention another potential mechanism of the action of investigated nitrofurans, such as their 2/4-electron reduction by oxygen-insensitive nitroreductase(s) [1, 6, 目. At present, the substrate specificity of these enzymes is uncharacterized, except the studies of nifurtimox, benznidazole, and a limited number of other compounds [1, 6, 7]. This problem deserves intensive studies in the future. Nevertheless, our data demonstrate that the efficient inhibition of TR and a relatively high lipofilicity may be important factors enhancing the antitrypanosomal activity of nitroaromatic compounds.

\section{CONCLUSIONS}

Several 5-vinylquinoline-substituted nitrofurans, used in this study, acted as efficient antitrypanosomal agents at micromolar concentrations. However, their future application may be limited due to a relatively high mammalian cell cytotoxicity. There exists a parallelism between their antitrypanosomal activity and efficacy as trypanothione reductase inhibitors. The inhibition of another enzyme of trypanothione metabolism, trypanothione synthetase, appears not to be a significant factor of the trypanocidal activity of examined compounds.

\section{ACKNOWLEDGEMENTS}

We thank Professor John S. Blanchard (Department of Biochemistry, Albert Einstein College of Medicine, Bronx, NY, USA) for his generous gift of trypanothione reductase and trypanothione. $\check{Z}$. A., J. Š. and N. Č. gratefully acknowledge the support of the European Social Fund (Measure No. 09.33LMT-K-712, Grant No. DOTSUT-34/09.3.3.-LMTK712-01-0058/LSS-600000-58). The financial support of ANII, Uruguay, is gratefully acknowledged by D. B. (POS_NAC_2013_1_114477) and M. A. C. (Project DCIALA/2007/19.040). M. A. C. acknowledges the support of Institut Pasteur ACIP call 2015 (Project ACIP 17-2015). J. Š and M. A. C. acknowledge the support of COST Actions CM0801 and CM1307.

Received 25 February 2020 Accepted 12 March 2020

\section{References}

1. S. R. Wilkinson, C. Bot, J. M. Kelly, B. S. Hall, Curr. Top. Med. Chem., 11, 2072 (2011).

2. E. Pelfrene, M. Harvey Altchurch, N. Ntamabyaliro, et al., PLoS Negl. Trop. Dis., 13, e0007381 (2019).

3. C. Giulivi, J. F. Turrens, A. Boveris, Mol. Biochem. Parasitol., 30, 243 (1988).

4. G. B. Henderson, P. Ulrich, A. H. Fairlamb, et al., Proc. Natl. Acad. Sci. USA, 85, 5374 (1988).

5. R. Docampo, Chem. Biol. Interact. 73, 1 (1990).

6. B. S. Hall, C. Bot, S. R. Wilkinson, J. Biol. Chem., 286, 13088 (2011). 
7. B. S. Hall, S. R. Wilkinson, Antimicrob. Agents Chemother, 56, 115 (2012).

8. N. Čènas, D. Bironaitè, E. Dičkancaitè, Ž. Anusevičius, J. Šarlauskas, J. S. Blanchard, Biochim. Biophys. Res. Commun., 204, 224 (1994).

9. D. G. Arias, F. E. Herrera, A. S. Garay, et al., Eur. J. Med. Chem., 125, 1088 (2017).

10. C. Dumas, M. Quelette, J. Tovar, et al., EMBO J., 16, 2590 (1997).

11. M. A. Comini, S. A. Guerero, S. Haile, H. Lünsdorf, L. Flohe, Free Radic. Biol. Med., 36, 1289 (2004).

12. A. H. Fairlamb, A. Cerami, Annu. Rev. Microbiol., 46, 695 (1992).

13. N. Tiwari, N. Tanwar, M. Munde, Arch. Pharm. Life Sci., 351, e1700373 (2018).

14. E. M. Jacoby, I. Schlichting, C. B. Lantwin, W. Kabsch, R. L. Krauth-Siegel, Protein. Struct., Funct. Genet., 24, 73 (1996).

15. A. Marozienè, M. Lesanavičius, E. Davioud-Charvet, et al., Molecules, 24, 4509 (2019).

16. D. Benitez, A. Medeiros, L. Fiestas, et al., PLoS Negl. Trop. Dis., 10, e0004617 (2016).

17. P. Grellier, J. Šarlauskas, Ž. Anusevičius, et al., Arch. Biochem. Biophys., 393, 199 (2001).

18. F.X. Sullivan, S. L. Shames, C. T. Walsh, Biochemistry, 28, 4986 (1989).

19. J. Šarlauskas, L. Misevičienè, A. Marozienè, et al., Int. J. Mol. Sci., 15, 23307 (2014).

20. J. Franco, F. Sardi, L. Szilagyi, K. E. Kover, K. Feher, M. A. Comini, Int. J. Parasitol. Drugs Drug Resist., 7, 303 (2017).

21. B. Demoro, C. Sarniguet, R. Sanchez-Delgado, et al., Dalton Trans., 41, 1534 (2012).

22. V. Miliukienè, N. Čènas, Z. Naturforsch. C, 63, 519 (2008).
23. M. C. Taylor, J. M. Kelly, C. J. Chapman, A. H. Fairlamb, M. A. Miles, Mol. Biochem. Parasitol., 64, 293 (1994).

24. R. De Gasparo, E. Brodbeck-Persch, S. Bryson, et al., ChemMedChem, 13, 957 (2018).

25. R. De Gasparo, O. Halgas, D. Harangozo, et al., Chem. Eur. J., 25, 11416 (2019).

Diego Benitez, Marcelo A. Comini,

Žilvinas Anusevičius, Jonas Šarlauskas,

Valè Miliukienè, Eglè Miliuvienė, Narimantas Čènas

\section{5-VINILCHINOLIN-PAVADUOTI}

NITROFURANAI KAIP

TRIPANOTIONREDUKTAZĖS INHIBITORIAI IR ANTITRIPANOSOMINIAI AGENTAI

Santrauka

Tripanotionreduktazé (TR) ir tripanotionsintetazé (TS) atlieka svarbias antioksidacines funkcijas ir palaiko tiolių redokso homeostazę tripanosominiuose parazituose, sukeliančiuose afrikietiškają miego ir Čagos ligas. Šių fermentų neturi žinduoliai, todèl efektyvūs ir selektyvūs TR inhibitoriai yra vienas iš naujų antitripanosominių vaistų kūrimo būdų. Šiame darbe ištirti 5-vinilchinolin-pavaduoti nitrofuranai $(n=7)$ buvo be- arba nekonkurentiniai tripanotiono atžvilgiu Trypanosoma congolense TR inhibitoriai. Ju inhibicijos konstantos $\left(K_{i}\right)$ kito nuo $2,3 \mu \mathrm{M}$ iki $150 \mu \mathrm{M}$. Pirmą kartą atskleideme ryši tarp tirtų junginių antitripanosominio in vitro aktyvumo ir jų aktyvumo inhibuojant TR. TS inhibicija tirtais junginiais, tikètina, nèra svarbus jų antitripanosominio poveikio veiksnys. 